\title{
Workplace Drug Testing: An Overview of the Current Situa-
}

\section{tion}

Keywords: Workplace drug testing; Drug consumption; Europe; Hair; Oral fluid; Urine

\begin{abstract}
Background: Almost a quarter of the adult population in the European Union are estimated to have used illicit drugs at some point in their lives. Since these substances can be found at home, on the road, in leisure, it can be assumed that also exist in the workplace, even if they are more difficult to detect. In the workplace, psychoactive substances use may have important implications for workers, thus affecting the tasks to be carried out in their work environment.

Objective: This article reviews how the different countries implement the workplace drug testing (WDT) as necessary tool in order to play a deterrent role on the abuse behavior.

Discussion: At a European level there is no specific legislation on drug testing at the workplace. WDT is performed on a much smaller scale than in the United States, though it is on the increase. It is also important to discriminate between workers under the influence of these substances at work than those who consume regularly but are not under the influence of drugs at work. In conclusion we can say that there is a growing interest in WDT, but the costs and benefits that these controls may represent remain unknown.
\end{abstract}

\section{Introduction}

According to the International Labour Organization (ILO) a psychoactive substance is any substance consumed by a person to change how to feel, to think or how to behave [1]. Thus, psychoactive substances are considered to be alcohol, illicit drugs and even legal drugs either consumed with or without medical prescription [2].

Almost a quarter of the adult population in the European Union (EU), or over 80 million adults, are estimated to have used illicit drugs at some point in their lives. In most cases, they have used cannabis (73.6 million), with lower estimates reported for the lifetime use of cocaine (14.1 million), amphetamines (11.4 million) and ecstasy (10.6 million). Cannabis is the illicit drug most likely to be used by all age groups; $21.7 \%$ of adults (15-64 years) used cannabis in their lifetime [3]. Cannabis use is generally higher among males, and this difference is usually pronounced for more intensive or regular patterns of use. Cocaine is the most commonly used illicit stimulant drug in EU (4.2\% of adults), although most users are found in a restricted number of countries such as Denmark, Spain and the United Kingdom. A growing number of new drugs that are detected on the drug market have been approved as medicines. Recent examples include: phenazepam, a benzodiazepine, which has been sold as a legal benzodiazepine (as medicine), as a research chemical (as a chemical product) and as the controlled drug diazepam [3].

As it appears that psychoactive substance can be found at home, on the road, in leisure, one cannot assume they do not exist in the workplace, even if they are less visible and/or more difficult to detect their consumption [2].

\section{Journal of} Toxins

\section{Patricia Horno ${ }^{1}$, Agustín Gonález-Padrón ${ }^{2}$ and Isabel M. Moreno ${ }^{3^{*}}$}

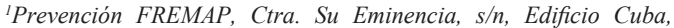
41006, Sevilla, Spain

${ }^{2}$ Instituto Nacional de Toxicología y Ciencias Forenses, Sevilla, Avda., Doctor Fedriani s/n, 41071, Spain

${ }^{3}$ Area of Toxicology, Faculty of Pharmacy, University of Sevilla, Sevilla, Spain

\section{*Address for Correspondence}

Isabel M. Moreno, Area of Toxicology, Faculty of Pharmacy, University of Sevilla, Sevilla, Spain, Tel: +34 954 556762; Fax: +34 954 233765; E-mail: imoreno@us.es

Submission: 15 March, 2016

Accepted: 30 March, 2016

Published: 04 April, 2016

Copyright: $\odot 2016$ Horno P, et al. This is an open access article distributed under the Creative Commons Attribution License, which permits unrestricted use, distribution, and reproduction in any medium, provided the original work is properly cited.

Reviewed \& Approved by: Dr. Ashraf Mahmoud Emara, Clinical Toxicology, Tanta university, Egypt

In the workplace, psychoactive substances use may have important implications for workers, thus affecting the tasks to be carried out in their work environment as by the social and health problems that can be generated. Furthermore, in some cases the use of these substances may affect third, contributing to cause accidents. Also, some conditions or characteristics of the working environment or the type of work, or the fact of not having it may act as risk factors or protective drug use [4].

All psychoactive substances have, to a higher or lesser extent, a negatively impact on work capability. Acute consumption of alcohol can induce since a concentration reduction to a deficiency in psychomotor coordination depending on the level of its consumption. The majority of alcohol-related work-performance problems are associated with nondependent drinkers who may occasionally drink too much [5]. Cannabis acutely reduces some cognitive and psychomotor skills, such as motor control, psychomotor speed, executive function, motor impulsivity, visual processing, short-term memory, working memory (reaction time and accuracy), perception and balance, and these effects are mostly dose dependent [6-13]. Chronic use of cannabis can lead to deficiencies in memory, attention, manual dexterity, executive functioning and psychomotor speed [14-17]. These effects can last longer than the period of intoxication and worsen with either increasing number of years or frequency of cannabis use. The defects are partially reversible with prolonged abstinence, but some impairment may be permanent. Cocaine has a psychomotor stimulant effect and has a strong reinforcing action, causing a rapid psychological dependence [18]. Chronic use of cocaine can cause deficiencies in users, such as difficulties in processing cognitive tasks concerning attention, visuospatial perception, memory, cognitive flexibility, perceptualmotor speed, problem-solving, abstraction and executive functioning [19-25]. Amphetamine is a central nervous system stimulant that causes serious cardiovascular disturbances as well as behavioral 
problems that include agitation, confusion, paranoia, impulsivity and violence after an acutely use. Chronic use of amphetamine results in deficits in memory and in decision-making and verbal reasoning. Benzodiazepines are a group of substances that cause impairment ranging from severe effects to almost no effect. With chronic and subchronic use, tolerance might develop, partially or completely, to the impairing effects. Effects on daytime performance may diminish over time as a result of tolerance [18].

The main goal of this paper is to review the present situation of the workplace drug testing, especially in countries from the European Union where there is no specific legislation in contraposition with United States or Australia. Furthermore, authors intend to stress the importance of knowing the specific drug consumption trends in each country in order to include them in the routine tests in Workplace Programmes and the main biological samples and analytical methods are reviewed and discussed in order to select the best methodology depending of the goals and regulatory requirements.

\section{Method}

A systematic literature search was undertaken to locate and review research concerning the workplace drug testing. The review was designed to answer the following questions:

Which countries have implemented the workplace drug testing?

Does exists at a European level a specific legislation and regulation on drug testing at the workplace?

Which are the most important biological samples and analytical methods for WDT?

\section{Search strategy}

The Medline, Scopus and Web of knowledge citation databases were searched for relevant articles published between 1995-2015

\begin{tabular}{|l|l|l|l|}
\hline \multicolumn{1}{|c|}{$\begin{array}{c}\text { Workplace drug } \\
\text { testing }\end{array}$} & \multicolumn{1}{|c|}{ WDT } & \multicolumn{1}{|c|}{ Europe } & \multicolumn{1}{c|}{ Alcohol } \\
\hline Prevalence & Illicit drugs & Urine & Oral fluid \\
\hline Hair & Analytical methods & & LC-MS/MS \\
\hline
\end{tabular}

using combinations of the following terms:

A total of 8727 articles were identified only using workplace drug testing term. After the first examination of reference list provided, the search were refine with a year filter (articles published 2000-2015) obtaining a list of 3579 articles. Of these only 700 focus on WDT, prevalence and Europe; 503 on WDT, alcohol and illicit drugs and 148 on WDT, analytical methods, LC-MS/MS, urine, oral fluid and hair. Once removed the duplicates and those that were not relevant for this review, the remaining articles were classified according the main focus of each article. The majority were descriptions and analysis of testing programs in countries from Europe mainly and others as US, Brazil, New Zealand, and Turkey. Ten were literature reviews, of which seven focused on evaluations of the drug testing in the workplace and the other three were reviews about analytical methods for determination of drugs of abuse. Of the remaining articles, two classifications were made, once for those focus on prevalence of drug consumptions among workers stratified or not and other for articles focus on analytical methods for detecting drugs in different biological samples. This resulted in 77 included articles and 4 public documents obtained though internet sites:

http://staging.ilo.org/public/libdoc/ilo/2003/103B09_10_engl. pdf

http://www.emcdda.europa.eu/publications/edr/trendsdevelopments/2014

http://www.pnsd.msssi.gob.es/profesionales/ sistemasInformacion/sistemaInformacion/pdf/Encuesta20072008AmbitoLaboral.pdf

http://www.emcdda.europa.eu/publications/drug-profiles

\section{Workplace Drug Testing}

Prevention strategies must encompass all substances of abuse, not just illicit ones. Countries must give more weight to remedial elements in a public health context and learn from each other experiences of successful prevention strategies [26]. In this sense, workplace drug testing (WDT) is an increasingly necessary tool in order to play a deterrent role on the abuse behavior. This perception becomes even stronger in some specific activities, such as the transportation sector in which the erroneous action of one worker can endanger the safety of thousands of persons [27]. However, when employees are asked for their perception about these screenings, those whose are working in certain jobs (hospitality, sales, food industry, etc.) felt that drug tests are a waste of time and resources by the company, because the test can be manipulated and the job duties are not complex [28].

WDT takes three forms: pre-employment drug testing, testing for cause, and random testing. In the United States, where WDT began, it is widespread. Drug testing guidelines and processes are established and regulated by the Substance Abuse and Mental Health Service Administration (SAMHSA) [29]. In order to ensure a drugfree workplace, all federal employees are required to pass a urine drug test before employment [30]. Between 67 and $80 \%$ of US corporations have WDT programmes, however alcohol testing in US workplaces is much less common [31]. The prevailing approach is to use the test not to identify someone in need of treatment but to identify a person who should be removed from the workplace [32]. The US goal to promote a drug-free workplace does not appear to be reasonable to other countries given the invasiveness of the approach. Rather, one potential motivation for drug testing programs in other countries is to improve safety and productivity by reducing the incidence risk of alcohol or drug related injuries and accidents [33,34]. In Australia and New Zealand, the requirements for workplace drugs and alcohol testing are stipulated in Australian standards [29]. These standards are used as a voluntary guideline for WDT in Australia but they are not specific to WDT. A steady increase in Companies in the highrisk industries (construction, transportation, etc.) embracing the comprehensive approach with a focus on education and rehabilitation harmoniously supporting the testing regime has been observed in New Zealand [35]. The decision to implement WDT program in Brazilian business companies is based on matters of employees' health and safety. Although is not mandatory, more than 300 companies have been participating in WDT programs involving the attempt to reduce absenteeism in the workplace and incompatibility of drug use with some jobs [36]. In Turkey, even though WDT is not well defined, it is 
increasingly being used in the criminal justice system and in sports. The main regulations on workplace drug use/abuse exist in the Turkish Penal Code, the Labour Law, Workplace Physicians Regulations and Transport System (highway and maritime). In Turkey, drug testing is mandatory only for sailors since February 2011 [37].

At a European level there is no specific legislation and regulation on drug testing at the workplace. It has been attempted, however, through the European Workplace Drug Testing Society (EWDTS), to draft some specific guidelines. Nevertheless, WDT in Europe is performed on a much smaller scale than in the United States, though it is on the increase $[29,38]$. Drug and alcohol testing must be placed within the larger context of moral and ethical issues. Individual rights and collective rights of society have to be taken into account [39].

The European Union (EU) is made up of 28 different countries. Of these only 19 are in the Eurozone. WDT seems to be most developed in the United Kingdom and Scandinavia, neither of which is in the Eurozone [38]. In 2001, the United Kingdom Workplace Drug Testing Forum finalized its guidelines for legally defensible WDT; it is common practice for employers to require pre-employment testing in order to identify those individuals that can pose risks to the safety of themselves and others [40,41]. WDT in Sweden is increasing and new regulations since 2010 have introduced random testing at airports. That is unique in Europe and for many years, the air traffic controllers have also been drug tested randomly [29]. In Finland, WDT is mainly performed in accordance with the Act on the Protection of Privacy in Working Life, the Occupational Health Care Act and the Decree on Workplace Drug Testing. These regulations must ensure the integrity and protection of privacy of the persons tested as well as their other fundamental rights $[39,42]$. The employer must have a written occupational health care and occupational health care needs based on workplace conditions. Alcohol and drug problems should be considered as health problems and they should be dealt with the same way as any other health problem at work [43]. In Norway, WDT is mainly done within the transport, petrochemical, shipping, automobile, pharmaceutical and computer industries, by mutual agreement between the employee and the company [44]

In Italy, the Decree on Health and Safety at Work, entered in April 2008 and prescribes mandatory drugs tests for jobs which pose safety hazards to others, but pre-employment test are forbidden. The functions taking into account by the law can be divided into two major groups: functions for which a special qualification or licence is required and functions concerning transport activities $[45,46]$.

In Portugal, the WDT programs exist with legal support, based on the recognition by the major legal authorities, that the collective safety and health outweighs the individual rights to privacy. WDT is mainly performed in the military and transport and communication industry $[2,38]$. On the contrary, in Spain, WDT faces restrictions regarding individual rights and data protection law. WDT is mainly performed in the police and military organization. Union will not usually initiate drug testing policies; employers will generally place those policies on the negotiating tables included in a programme of prevention of addictions designed to identify illicit drug users but never for removing them from the workplace. The drug users identified will be informed about health risks and treatment options.

The economic benefits of treatment programs with respect to absenteeism, tardiness and productivity have been observed by Arbour et al. over 5-year and 13-year periods of treatment; however there is little statistically relevant evidence of the presumed causal link between individual subjection to tests and subsequent accident reduction $[2,47]$.

Drug testing programs can be very costly for a company, and their effectiveness in mitigating employee drug use is often uncertain. The full costs and benefits of WDT remain largely unknown because most empirical work is sparse in this area and sometimes results are compromised by the low prevalence rates for most illicit drugs [48]. One reason for this low prevalence may be that WDT is only likely to identify frequent users and most employees that use drugs do so infrequently [34]. For this reason the quantity and frequency of drug use may be an important factor in this relationship in that heavier

Table 1: Prevalence of alcohol and drugs obtained through surveys or results of WDT in working age population and in stratified prevalence studies.

\begin{tabular}{|c|c|c|c|c|c|c|}
\hline Country & $\begin{array}{c}\text { Alcohol Prevalence } \\
(\%)\end{array}$ & $\begin{array}{c}\text { Illicit drugs } \\
\text { Prevalence } \\
\text { (\%) }\end{array}$ & Drugs detected & Survey/ WDT & Profession & References \\
\hline Australia & 8.7 & 0.9 & --- & Survey & $\begin{array}{l}\text { Working-age } \\
\text { population }\end{array}$ & [49] \\
\hline Spain & 15.3 & 1.8 & --- & Survey & $\begin{array}{l}\text { Working-age } \\
\text { population }\end{array}$ & {$[4]$} \\
\hline Brazil & & 1.8 & $\begin{array}{c}\text { Cannabis } \\
\text { Cocaine } \\
\text { Amphetamine }\end{array}$ & WDT & $\begin{array}{l}\text { Working-age } \\
\text { population }\end{array}$ & [36] \\
\hline United Kingdom & & 19 & $\begin{array}{c}\text { Cannabis } \\
\text { Opiates } \\
\text { BZ }\end{array}$ & WDT & $\begin{array}{l}\text { Working-age } \\
\text { population }\end{array}$ & [40] \\
\hline Italy & & 2 & $\begin{array}{l}\text { Cannabis } \\
\text { Cocaine }\end{array}$ & WDT & $\begin{array}{l}\text { Working-age } \\
\text { population }\end{array}$ & {$[46,50]$} \\
\hline Italy & & 0.7 & $\begin{array}{l}\text { Cannabis } \\
\text { Cocaine }\end{array}$ & WDT & Hauliers & [45] \\
\hline Finland & & 1.6 & & WDT & Defense Force & {$[51]$} \\
\hline France & 5 & $\begin{array}{l}8.5 \\
4.1\end{array}$ & $\begin{array}{l}\text { Cannabis } \\
\text { Opiates }\end{array}$ & WDT & Truck Drivers & [53] \\
\hline
\end{tabular}


drug users may have a greater distaste for worksites with anti-drug programs relative to casual drug users and non-drug users [48].

\section{Prevalence of Drug Consumption}

It is necessary to know the specific drug trends in each country in order to include them in the routine tests for in Workplace Programmes. Such as, in New Zealand where after alcohol, cannabis is the most prevalent drug used, but LSD usage is relatively high compared with other countries. Meanwhile, cocaine abuse is low compared with global trends [35].

Studies on the prevalence of illicit drug use among employed and unemployed people are relatively scarce in the literature. In Table 1 are shown estimated prevalence in the workforce obtained through surveys in the case of Australia (Australian national household survey) and Spain (Household Survey on Alcohol and Drugs in Spain) $[4,49]$ and from the results of the WDT in other countries.

In this sense in Brazil, a study performed among workers of five Brazilian geographical regions from business companies that have adopted testing programs showed that the most consumed drugs were marijuana, cocaine, amphetamine and associated drugs [36]. The most common drug detected from WDT in UK was cannabis, followed by opiates and benzodiazepines [40]. In Italy cannabis (tetrahidrocannabinol) was the most frequent drug detected [50]. In a second stage testing included in WDT to confirm the urine positives detected it was proved the widespread and undeclared used of cocaine in this country [46].

Job quality seems to be a determining social factor of major importance with regard to explaining both individual as well as collective health, which can be mediated, in part, by the use of psychoactive substances. Besides, this complex relationship between employment and the use of psychoactive substances currently has one aspect of particular interest which is a result of the economic crisis we are experiencing, which could have a bearing on how the population is acting regarding drug use [4]. In this sense, it would be necessary therefore stratified prevalence studies depending on the type/quality of work. Prior research suggests that illicit drug use is more prevalent in the following occupation categories: Arts/entertainment/sports/ media; sales; food production and serving/hospitality; construction; building and grounds maintenance, and transportation and material moving [28]. Results obtained by Edvardsen et al. and Meririnne et al. in both studies about using of alcohol and drugs among health professionals in Norway and in the Finnish Defence Force respectively; conclude that illicit drug use is rare among these kinds of employees (Table 1) [44,51]. On the contrary, a study about describing the patterns of alcohol use among persons employed within safety and security positions showed the potentially higher risk for developing alcohol-related disorders Burnhams et al. [52]. On the other hand, prevalence for opiates, cannabis and ethanol studied among French truck driver and hauliers working in different Italian

Table 2: Differences between urine, oral fluid and hair as biological samples used it in WDT.

\begin{tabular}{|c|c|c|c|c|c|}
\hline Specimen & Detection Periods & Drugs detected & Advantages & Disadvantages \\
\hline Urine & Days-Weeks & $\begin{array}{c}\text { Metabolites indicative of use of } \\
\text { cannabis, cocaine, opiates and } \\
\text { amphetamines }\end{array}$ & $\begin{array}{c}\text { Non invasive } \\
\text { Fast and easy to collect } \\
\text { Well-established methods }\end{array}$ & $\begin{array}{c}\text { Easy to dilute, adulterate or } \\
\text { substitute }\end{array}$ \\
\hline Oral Fluid & 24-48 Hours & Parent drugs in high proportion & Non invasive & Fast and easy to collect & $\begin{array}{c}\text { Low concentration range } \\
\text { Variable pH } \\
\text { Possible contamination with } \\
\text { drug residues in nasal cavity }\end{array}$ \\
\hline Hair & Month-Years & Parent drugs and metabolites & $\begin{array}{c}\text { Fast and easy to collect } \\
\text { Greater stability versus } \\
\text { body fluids }\end{array}$ & $\begin{array}{c}\text { Differences in hair growth } \\
\text { and mechanism of drug } \\
\text { incorporation } \\
\text { Requires trained and } \\
\text { experienced scientists }\end{array}$ \\
\hline
\end{tabular}

Table 3: Methods to identify drugs in urine, oral fluid, and hair.

\begin{tabular}{|c|c|c|c|c|}
\hline Specimen & Extraction procedure & Detection technique & Drugs & References \\
\hline Urine & SPE & $\begin{array}{c}\text { LC-MS } \\
\text { LC-MS/MS }\end{array}$ & $\begin{array}{l}\text { Illicit drugs } \\
\text { Hallucinogens }\end{array}$ & [68-70] \\
\hline Urine & LLE & LC-MS/MS & $\begin{array}{l}\text { Amphetamines and amphetaminic } \\
\text { compounds }\end{array}$ & {$[71]$} \\
\hline Urine & SPE & UPLC-MS/MS & 12 illicit drugs & [72] \\
\hline Urine & SPE & UPLC-MS/MS & 23 opioids, cocaine and metabolites & [73] \\
\hline Saliva & LLE & $\begin{array}{c}\text { LC-MS } \\
\text { LC-MS/MS }\end{array}$ & $\begin{array}{l}\text { Benzodiazepines } \\
\text { Antidepressants }\end{array}$ & $\begin{array}{l}{[63]} \\
{[64]}\end{array}$ \\
\hline Oral fluid & LLE & LC-MS/MS & 32 licit and illicicit drugs & {$[74]$} \\
\hline Oral fluid & SPE & LC-MS/MS & 21 illicit and medicinal drugs & [75] \\
\hline Hair & Incubation with mobile phase & $\begin{array}{c}\text { GC-MS } \\
\text { LC-MS/MS }\end{array}$ & $\begin{array}{l}\text { Opiates and amphetamines } \\
\text { Benzodiazepines }\end{array}$ & [76] \\
\hline Hair & Two steps: LLE+SPE & LC-MS/MS & 35 licit and illicicit drugs & [77] \\
\hline
\end{tabular}


regions were higher than in the general population (Table 1) $[45,53]$. Construction work is hazardous and workers consistently rank in the top of all occupations and industries for illicit drug and heavy alcohol use [54]. In this sense, a survey about workplace stress, stress effects and coping mechanism in the construction industry were performed by Bowen et al. reporting that workplace stress is linked to excessive drinking and using of illegal substances [55]. Similarly, Collel et al. examined the association between work-related stress and alcohol use in a representative sample of the Spanish working population [56]. They concluded that although occupational environments contribute to maintaining or exacerbating potentially damaging drinking behaviors may be modest, identifying work features that affect vulnerable individuals may still be useful for prevention purposes. Thus, drug testing at work is a complex interdisciplinary issue and workplace injury prevention programs should address the expression of problem behaviors as a complement to drug and alcohol deterrent programs [57].

\section{Biological Matrices for Drug Testing}

Pharmacokinetic studies of drugs in the body following absorption show that the processes of metabolism, distribution and elimination mean that there is a wide distribution of parent drugs and their metabolites between the various biological compartments. For this reason the use of biological fluids is universally accepted for the detection and monitoring of drug use [41]. The selection of the best specimen for drug analysis is influenced by a variety of factors, principally ease of specimen collection, analytical and testing considerations, and interpretation of results [58]. In Table 2 all these factors are summarized comparing urine, oral fluid and hair as the main biological samples for drug analysis.

\section{Analytical Methods for Drug Testing}

There are two stages in the drug testing protocol; the first step consists of random sample collection and screening test using the immunoassay as the initial test on each specimen. If the immunoassay is positive, this result must be confirmed in a second step by gas chromatography-mass spectrometry (GC-MS) or liquid chromatography mass spectrometry (LC-MS) analysis [46,59]. In addition, testing different biological matrices offers unique information about the drug-use history of an individual [60]. In Table 3 is presented a summary of the different extraction techniques used to provide thorough clean-up of the matrix and the combination with LC-DAD, LC-MS or LC-MS/MS for the simultaneous determination of medicinal and illicit drugs in urine, oral fluid and hair.

\section{Conclusion}

In summary, we can say that there is a growing interest in WDT, being Europe behind USA in its implementation. This perception becomes even stronger in some specific activities, such as the transportation sector, health professional, etc. On the contrary, the full costs and benefits of WDT remain unknown. It is necessary to know the prevalence of illicit drugs use and the specific drug trends in each country in order to include them in the routine tests for in workplace programmes.

The recommended samples in order to avoid adulterations, substitution or dilution as happens with urine, are oral fluid and hair. A positive finding in oral fluid indicates drug use during the past 24-48 hours. Hair has a longer detection window enabling retrospective investigation of chronic and past consumption. In order to discriminate between workers under the influence of drugs at the time of sampling (at work) than those who consume regularly but are not under the influence of drugs at work it would be advisable sampling both oral fluid and hair.

\section{References}

1. ILO (2003) Drug testing. In: Alcohol and drug problems at work-The shift to prevention. International Labour Organisation, Geneve, pp. 79-88.

2. Marques $\mathrm{PH}$, Jacinto $\mathrm{C}$ (2014) Screening for psychoactive substances at the workplace: a review. In: Arezes PM, Baptista JS, Barroso MP, Carneiro $\mathrm{P}$, Cordeiro $\mathrm{P}$, et al. (Eds). Occupational safety and hygiene II, CRC Press, Taylor \& Francis Group, London, pp. 429-433.

3. EMCDDA (2014) European Drug Report 2014: Trends and Developments. European Monitoring Centre for Drugs and Drug Addiction.

4. OEDT (2015) Encuesta 2007-2008 sobre consumo de sustancias psicoactivas en el ámbito laboral en España: Observatorio Español Sobre Drogas.

5. Salonsalmi A, Laaksonen M, Lahelma E, Rahkonen O (2009) Drinking habits and sickness absence: the contribution of working conditions. Scand J Public Health 37: 846-854.

6. Kurzthaler I, Hummer M, Miller C, Sperner-Unterweger B, Günther V et al. (1999) Effect of cannabis use on cognitive functions and driving ability. J Clin Psychiatry 60: 395-399.

7. Sexton BF, Tunbridge RJ, Brook-carter N, Jackson PG, Wright K, et al. (2000) The influence of cannabis on driving: TRL Report 477. Transport Research Laboratory. Wokingham, United Kingdom.

8. Hart CL, van Gorp W, Haney M, Foltin RW, Fischman MW et al. (2001) Effects of acute smoked marijuana on complex cognitive performance. Neuropsychopharmacology 25: 757-765.

9. Liguori A, Gatto CP, Jarrett DB (2002) Separate and combined effects of marijuana and alcohol on mood, equilibrium and simulated driving. Psychopharmacology 163: 399-405.

10. Ilan AB, Smith ME, Gevins A (2004) Effects of marijuana on neurophysiological signals of working and episodic memory. Psychopharmacology 176:214-222.

11. Nicholson AN, Turner C, Stone BM, Robson PJ (2004) Effect of Delta-9tetrahydrocannabinol and cannabidiol on nocturnal sleep and early-morning behavior in young adults. J Clin Psychopharmacol 24: 305-313.

12. Menetrey A, Augsburger M, Favrat B, Pin MA, Rothuizen LE, et al. (2005) Assessment of driving capability through the use of clinical and psychomotor tests in relation to blood cannabinoids levels following oral administration of $20 \mathrm{mg}$ dronabinol or of a cannabis decoction made with 20 or $60 \mathrm{mg}$ Delta9THC. J Anal Toxicol 29: 327-338.

13. Ramaekers JG, Kauert G, van Ruitenbeek $P$, Theunissen EL, Schneider E et al. (2006) High-potency marijuana impairs executive function and inhibitory motor control. Neuropsychopharmacology 31: 2296-2303.

14. Ehrenreich H, Rinn T, Kunert HJ, Moeller MR, Poser W et al. (1999) Specific attentional dysfunction in adults following early start of cannabis use. Psychopharmacology (Berl) 142: 295-301.

15. Pope HG Jr, Gruber AJ, Hudson JI, Huestis MA, Yurgelun-Todd D (2001) Neuropsychological performance in long-term cannabis users. Arch Gen Psychiatry 58: 909-915

16. Bolla KI, Funderburk FR, Cadet JL (2000) Differential effects of cocaine and cocaine alcohol on neurocognitive performance. Neurology 54: 2285-2292.

17. Solowij N, Stephens RS, Roffman RA, Babor T, Kadden R, et al. (2002) Cognitive functioning of long-term heavy cannabis users seeking treatment. JAMA 287: 1123-1131.

18. EMCDDA (2015) drug profiles. European Monitoring Centre for Drugs and Drug Addiction. 
19. Smelson DA, Roy A, Santana S, Engelhart C (1999) Neuropsychological deficits in withdrawn cocaine-dependent males. Am J Drug Alcohol Abuse 25: 377-381.

20. Di Sclafani V, Tolou-Shams M, Price LJ, Fein G (2002) Neuropsychological performance of individuals dependent on crack-cocaine, or crack-cocaine and alcohol, at 6 weeks and 6 months of abstinence. Drug Alcohol Depen 66: 161-171.

21. Lawton-Craddock A, Nixon SJ, Tivis R (2003) Cognitive efficiency in stimulant abusers with and without alcohol dependence. Alcohol Clin Expl Res 27: 457464

22. Toomey R, Lyons MJ, Eisen SA, Xian H, Chantarujikapong S, et al. (2003) A twin study of the neuropsychological consequences of stimulant abuse. Arch Gen Psychiatry 60: 303-310.

23. Goldstein RZ, Leskovjan AC, Hoff AL, Hitzemann R, Bashan F, et al. (2004 Severity of neuropsychological impairment in cocaine and alcohol addiction: association with metabolism in the prefrontal cortex. Neuropsychologia 42 1447-1458.

24. Kelley BJ, Yeager KR, Pepper TH, Beversdorf DQ (2005) Cognitive impairment in acute cocaine withdrawal. Cogn Behav Neurol 18: 108-112.

25. Rahman Q, Clarke CD (2005) Sex differences in neurocognitive functioning among abstinent recreational cocaine users. Psychopharmacology (Berl) 181: $374-380$.

26. Dalen P, Beck O, Bergman U, Björklöv P, Finer D, et al. (2000) Workplace drug testing (WDT) likely to increase in Europe. Report from the Firs European Symposium on WDT including selected abstracts. Eur J Clin Pharmacol 56: 103-120.

27. Marques PH, Jesus V, Olea SA, Vairinhosd V, Celeste Jacintof (2014) The effect of alcohol and drug testing at the workplace on individual's occupational accident risk. Safety Sci 68: 108-120.

28. Thomas LY, Kitterlin M, Moll L (2014) Pre-Employment Drug Testing fo Hospitality Sales Positions: Who's Buying In? J Hum Resour Hospit Tourism 13: $297-322$.

29. Pierce A (2012) Regulatory aspects of workplace drug testing in Europe. Drug Test Anal 4: 62-65.

30. Phan HM, Yoshizuka K, Murry DJ, Perry PJ (2012) Drug testing in the workplace. Pharmacotherapy 32: 649-656

31. Warren S, Wray-Bliss E (2009) Workforce drug testing: a critique and reframing. New Tech Work Employ 24: 163-176.

32. Oleson C (2004) Negotiating and teaching workplace drug testing: a labor perspective. Labor Stud J 28: 67-86

33. Mcdonald S (1997) Work-place alcohol and other drug testing: a review of the scientific evidence. Drug Alcohol Rev 16: 251-259.

34. Pidd K, Roche AM (2014) How effective is drug testing as a workplace safety strategy? A systematic review of the evidence. Accident Anal Prev 71: 154165

35. Nolan S (2008) Drug-free workplace programmes: New Zealand perspective. Forensic Sci Int 174: 125-132.

36. Silva OA, Yonamine M (2004) Drug abuse among workers in Brazilian regions. Rev Saúde Pública 38: 552-556.

37. Akgur SA, Erdem A, Coskunol H (2012) Legal workplace policies for drugs and alcohol in Turkey. Drug Test Anal 4: 74-75.

38. Verstraete AG, Pierce A (2001) Workplace drug testing in Europe. Forensic Sci Int 121: 2-6.

39. Lillsunde P, Haavanlammi K, Partinen R, Mukala K, Lamberg M (2008) Finnish guidelines for workplace drug testing. Forensic Sci Int 174: 99-102.

40. George S (2005) A snapshot of workplace drug testing in the UK. Occup Med (Lond) 55: 69-71.

41. Tsanaclis LM, Wicks JF, Chasin AA (2012) Workplace drug testing, different matrices different objectives. Drug Test Anal 4: 83-88.
42. Lamberg ME, Kangasperko R, Partinen R, Lillsunde P, Mukala K, et al. (2008) The Finnish legislation on workplace drug testing. Forensic Sci Int 174: 95-98.

43. Lillsunde $P$, Mukala K, Partinen R, Lamberg M (2008) Role of occupational health services in workplace drug testing. Forensic Sci Int 174: 103-106.

44. Edvardsen HM, Karinen R, Moan IS, Oiestad EL, Christophersen AS, et al. (2014) Use of alcohol and drugs among health professionals in Norway: a study using data from questionnaires and samples of oral fluid. J Occup Med Toxicol 9: 8.

45. Santoro PE, De Nardis I, Fronterre P, Felli M, Martello S, et al. (2012) A snapshot of workplace drug testing in Italy. Drug Test Anal 4: 66-70.

46. Vignali C, Stramesi C, Morini L, San Bartolomeo P, Groppi A (2015) Workplace drug testing in Italy: findings about second-stage testing. Drug Test Anal 7: 173-177

47. Arbour S, Gavrysh I, Hambley JM, Hambley JM, Psych C, et al. (2014) Addiction treatment and work-related outcomes: examining the impact of employer involvement and substance of choice on absenteeism, tardiness, and productivity. J Workplace Behav Health 29: 73-90.

48. French MT, Roebuck MC, Alexandre PK (2004) To test or not to test: do workplace drug testing programs discourage employee drug use? Soc Sci Res 33: 45-63.

49. Pidd K, Roche AM, Buisman-Pijlman F (2011) Intoxicated workers: findings from a national Australian survey. Addiction 106: 1623-1633.

50. Kazanga I, Tameni S, Piccinotti A, Floris I, Zanchetti G, et al. (2012) Prevalence of drug abuse among workers: strengths and pitfalls of the recent Italian Workplace Drug Testing (WDT) legislation. Forensic Sci Int 215: 4650

51. Meririnne E, Mykkanen S, Lillsunde P, Kuoppasalmi K, Lerssi R, et al. (2007) Workplace drug testing in a military organization: results and experiences from the testing program in the Finnish Defence Forces. Forensic Sci Int 170: 171-174

52. Burnhams NH, Parry C, Laubsche R, London L (2014) Prevalence and predictors of problematic alcohol use, risky sexual practices and other negative consequences associated with alcohol use among safety and security employees in the Western Cape, South Africa. Subst Abuse Treat Prev Policy 9: 14

53. Labat L, Fontaine B, Delzenne C, Doublet A, Marek MC, et al. (2008) Prevalence of psychoactive substances in truck drivers in the Nord-Pas-deCalais region (France). Forensic Sci Int 174: 90-94.

54. Schofield KE, Alexander BH, Gerberich SG, Ryan AD (2013) Injury rates, severity, and drug testing programs in small construction companies. J Safety Res 44: 97-104.

55. Bowen P, Edwards P, Lingard H, Cattell K (2014) Workplace stress, stress effects, and coping mechanisms in the construction industry. J Constr Eng Manage 140.

56. Collel E, Sánchez-Niubò A, Benavides FG, Delclos GL, Domingo-Salvany A (2014) Work-Related stress factors associated with problem drinking: a study of the Spanish working population. Am J Ind Med 57: 837-846.

57. Spicer RS, Miller TR, Smith GS (2003) Worker substance use, workplace problems and the risk of occupational injury: a matched case-control study. $J$ Stud Alcohol 64: 570-578.

58. Caplan YH, Goldberger BA (2001) Alternative specimens for workplace drug testing. J Anal Toxicol 25: 396-399.

59. Bush DM (2008) The U.S. mandatory guidelines for federal workplace drug testing programs: current status and future considerations. Forensic Sci Int 174: 111-119.

60. Huestis MA, Smith ML (2006) Modern analytical technologies for the detection of drug abuse and doping. Drug Discov Today Technol 3: 49-57.

61. Mcdonald S, Hall W, Roman P, Stockwell T, Coghlan M, et al. (2010) Testing for cannabis in the work-place: a review of the evidence. Addiction 105: 408416. 
62. Allen KR (2011) Screening for drugs of abuse: which matrix, oral fluid or urine? Ann Clin Biochem 48 (Pt 6): 531-541.

63. Quintela O, Cruz A, Castro Ad, Concheiro M, López-Rivadulla M, et al. (2005) Liquid chromatography-electrospray ionisation mass spectrometry for the determination of nine selected benzodiazepines in human plasma and oral fluid. J Chromatogr B Analyt Technol Biomed Life Sci 825: 63-71.

64. de Castro A, Concheiro M, Quintela O, Cruz A, López-Rivadulla M (2008) LC-MS/MS method for the determination of nine antidepressants and some of their main metabolites in oral fluid and plasma. Study of correlation between venlafaxine concentrations in both matrices. J Pharm Biomed Anal 48: 183193.

65. Fernández $\mathrm{P}$, Morales L, Vázquez C, Lago M, Bermejo AM (2008) Comparison of two extraction procedures for determination of drugs of abuse in human saliva by high-performance liquid chromatography. J Appl Toxicl 28: 998-1003.

66. Nakahara $Y$ (1999) Hair analysis for abused and therapeutic drugs. J Chromatogr B Biomed Sci Appl 733: 161-180.

67. Pragst F, Balikova MA (2006) State of the art in hair analysis for detection of drug and alcohol abuse. Clin Chim Acta 370: 17-49.

68. Tatsuno M, Nishikawa M, Katagi M, Tsuchihashi H (1996) Simultaneous determination of illicit drugs in human urine by liquid chromatography-mass spectrometry. J Anal Toxicol 20: 281-286.

69. Concheiro M, De Castro A, Quintela O, Cruz A, López-Rivadulla M (2007) Determination of illicit drugs and their metabolites in human urine by liquid chromatography tandem mass spectrometry including relative ion intensity criterion. J Anal Toxicol 31: 573-580.

70. del Mar Ramírez-Fernández M, Laloup M, Wood M, De Boeck G, LopezRivadulla M, et al. (2007) Liquid chromatography-tandem mass spectrometry method for the simultaneous analysis of multiple hallucinogens, chlorpheniramine, ketamine, ritalinic acid, and metabolites, in urine. J Anal Toxicol 31: 497-504.

71. Concheiro M, Simões SM, Quintela O, de Castro A, Dias MJ, et al. (2007) Fast LC-MS/MS method for the determination of amphetamine, methamphetamine, MDA, MDMA, MDEA, MBDB and PMA in urine. Forensic Sci Int 171: 44-51.

72. Zhang L, Wang ZH, Li H, Liu Y, Zhao M, et al. (2014) Simultaneous determination of 12 illicit drugs in whole blood and urine by solid phase extraction and UPLC-MS/MS. J Chromatogr B Analyt Technol Biomed Life Sci 955-956: 10-19.

73. Ramírez-Fernández Mdel M, Van Durme F, Wille SM, di Fazio V, Kummer $\mathrm{N}$, et al. (2014) Validation of an automated solid-phase extraction method for the analysis of 23 opioids, cocaine, and metabolites in urine with ultraperformance liquid chromatography-tandem mass spectrometry. J Anal Toxicol 38: 280-288.

74. Øiestad EL, Johansen U, Christophersen AS (2007) Drug screening of preserved oral fluid by liquid chromatography-tandem mass spectrometry. Clin Chem 53: 300-309.

75. Concheiro M, de Castro A, Quintela O, Cruz A, López-Rivadulla M, (2008) Determination of illicit and medicinal drugs and their metabolites in oral fluid and preserved oral fluid by liquid chromatography-tandem mass spectrometry. Anal Bioanal Chem 391: 2329-2338.

76. Kronstrand R, Nystrom I, Strandberg J, Druid H (2004) Screening for drugs of abuse in hair with ion spray LC-MS-MS. Forensic Sci Int 145: 183-190.

77. Lendoiro E, Quintela O, de Castro A, Cruz A, López-Rivadulla M, et al. (2012) Target screening and confirmation of 35 licit and illicit drugs and metabolites in hair by LC-MSMS. Forensic Sci Int 217: 207-215. 